\title{
Resveratrol-induced mitochondrial synthesis and autophagy in oocytes derived from early antral follicles of aged cows
}

\author{
Miyako SUGIYAMA ${ }^{1)}$, Ryoka KAWAHARA-MIKI'), Hirosuke KAWANA ${ }^{1)}$, \\ Koumei SHIRASUNA ${ }^{1 \text { ) }}$, Takehito KUWAYAMA ${ }^{1)}$ and Hisataka IWATA ${ }^{1)}$ \\ 1) Department of Animal Science, Tokyo University of Agriculture, Kanagawa 243-0034, Japan \\ ${ }^{2)}$ Research Institute Genome Research Center, Tokyo University of Agriculture NODAI, Tokyo 156-8502, Japan
}

\begin{abstract}
Mitochondrial numbers increase during oocyte growth. In this study, we collected oocytes and granulosa cell complexes (OGCs) from early antral follicles (EAFs) of aged cows (>120 months of age) and examined the effects of resveratrol on mitochondrial generation, degradation, and quality in oocytes grown in vitro. We also examined the effects of resveratrol on gene expression of the granulosa cells. Resveratrol $(20 \mu \mathrm{M})$ enhanced the expression of SIRT1 and induced autophagy in both granulosa cells and oocytes derived from aged cows. Culturing the OGCs with resveratrol increased mitochondrial DNA copy numbers in oocytes grown in vitro. Furthermore, resveratrol increased the ATP content in oocytes and improved the developmental ability of the oocytes to the blastocyst stage. Gene expression profiles in granulosa cells, as evaluated by next-generation sequencing technology, revealed that resveratrol enhanced the expression of EIF2-related genes but downregulated the expression of mammalian target of rapamycin (mTOR)-, inflammation-, and cholesterol homeostasisrelated genes in granulosa cells. In conclusion, resveratrol affected both oocytes and granulosa cells derived from aged cows and improved the quality of oocytes grown in vitro through upregulation of mitochondrial biogenesis and degradation in growing oocytes and conditioning of granulosa cells.
\end{abstract}

Key words: Early antral follicle, Gene expression, Granulosa cell, Mitochondria, Resveratrol

(J. Reprod. Dev. 61: 251-259, 2015)

M itochondria are crucial organelles that play important roles in energy metabolism, calcium homeostasis and apoptosis. Mitochondrial number increased during oocyte growth in vivo and in vitro [1,2], and the mitochondrial number (Mt number) in oocytes is important for oocyte quality, given the observed correlations between Mt numbers, fertilization, and developmental outcomes [3-6]. Additionally, reports have shown that aging decreases mitochondrial quality and quantity, which may be the primary causes of infertility in aged animals [3, 7-9]. The quality and quantity of mitochondria are regulated through the well-orchestrated processes of mitochondrial biogenesis and degradation in cells; mitochondrial biogenesis is regulated by mitochondrial transcription factor A (TFAM) and proliferator-activated receptor $\gamma(\mathrm{PPAR} \gamma)$ coactivator $1 \alpha(\mathrm{PGC} 1 \alpha)$, which are downstream of 5' AMP-activated protein kinase (AMPK) and sirtuin 1 (SIRT1) [10-12]. However, few reports have studied mitochondrial generation and degradation during oocyte growth.

The sirtuin family, which consists of seven family members in mammals, is a versatile protein family involved in whole-body metabolic homeostasis and has attracted attention as a potential resource for therapeutic applications. SIRT1, a member of the sirtuin

Received: January 9, 2015

Accepted: March 14, 2015

Published online in J-STAGE: April 12, 2015

(C2015 by the Society for Reproduction and Development

Correspondence: H Iwata (e-mail: h1iwata@nodai.ac.jp)

This is an open-access article distributed under the terms of the Creative Commons Attribution Non-Commercial No Derivatives (by-nc-nd) License $<\mathrm{http}: / /$ creativecommons.org/licenses/by-nc-nd/3.0/>. family, is predominantly localized in the nucleus and deacetylates a spectrum of transcriptional regulators localized in the nucleus and cytoplasm in an $\mathrm{NAD}^{+}$-dependent manner [13]. Resveratrol, a small polyphenol compound found in mulberries, peanuts, and grapes, functions through activation of SIRT1 [10, 14-16]. Supplementation of maturation medium with resveratrol has been reported to have beneficial effects in oocytes derived from young an aged cows, improving ATP content and fertilization outcomes in bovine oocytes $[17,18]$ and inducing de novo mitochondrial generation in porcine oocytes [19]. However, whether adding resveratrol to in vitro growth medium of oocytes derived from early antral follicles (EAFs) induces mitochondrial generation and degradation or improves the quality of oocytes grown in vitro has not yet been clarified.

Maternal aging-associated deterioration of oocytes is a common feature in mammals; however, no effective measures to counteract this process have been developed. Cows are commonly used as a model of maternal aging because their follicle selection system is similar to that in humans and because they have long reproductive lives [20-25]. In addition, low mitochondrial quality and quantity have been reported in bovine oocytes derived from antral follicles of aged cows [9]. Furthermore, the developmental ability of oocytes derived from EAFs of aged cows is low compared with those derived from younger cows, and the gene expression profiles of granulosa cells have been shown to differ between young and old cows [26].

In the present study, we examined the effects of resveratrol on Mt number and quality in aged oocytes. To this end, we collected oocytes and granulosa cell complexes (OGCs) derived from EAFs of aged cows and treated the OGCs with or without resveratrol for 
16 days. The effects of resveratrol on mitochondrial generation and degeneration during oocyte growth were examined. In addition, we examined the effects of resveratrol on gene expression profiles of granulosa cells. Our data provide important insights into the mechanisms of aging and mitochondrial regulation in oocytes.

\section{Materials and Methods}

\section{Media and chemicals}

Unless otherwise stated, all drugs were purchased from Nacalai (Kyoto, Japan). The TCM 199 medium (Gibco BRL, Paisley, UK) used for in vitro culture (IVC) of OGCs was supplemented with 5.56 $\mathrm{mM}$ glucose (final concentration, $11.2 \mathrm{mM}$ ), $0.1 \mathrm{mM}$ pyruvic acid, $0.1 \mu \mathrm{g} / \mathrm{ml}$ estradiol-17 $\beta$ (E2), 0.02 milliarbitrary units (mAU)/ml follicle-stimulating hormone (FSH; Kawasaki Mitaka Pharmaceutical, Kawasaki, Japan), 4\% polyvinylpyrrolidone (PVP; 360K), 4 mM hypoxanthine and $10 \%$ fetal calf serum (FCS; 5703H, ICN, Costa Mesa, CA, USA). Resveratrol (Wako, Tokyo, Japan) was dissolved in ethanol at a concentration of $20 \mathrm{mM}(\times 1000$ of final concentration $)$. The TCM 199 medium used for in vitro maturation (IVM) of oocytes contained $5 \%$ FCS. The medium used for IVF and culture of embryos was synthetic oviduct fluid (SOF) [27]. The SOF medium used for IVF was supplemented with $4 \mathrm{mg} / \mathrm{ml} \mathrm{BSA}$ and $10 \mathrm{U} / \mathrm{ml}$ heparin (Sigma-Aldrich, St. Louis MO, USA), and the medium used for IVC was supplemented with 5\% FCS and amino acids (essential and nonessential amino acids; Sigma).

\section{Collection of ovaries and oocytes from EAFs}

Japanese black cows over 120 months of age were used as aged donors, as reported previously $[9,17,28]$. Ovaries were collected from a slaughterhouse and transported to the laboratory in phosphatebuffered saline (PBS) containing antibiotics at $30 \mathrm{C}$ within $4 \mathrm{~h}$. The ovaries were wiped with $70 \%$ ethanol, the ovarian surface was sliced, and EAFs measuring 400-700 $\mu \mathrm{m}$ in diameter were collected. OGCs were retrieved from the EAFs using an 18 -G needle connected to a 1-ml syringe. Representative images of OGCs collected from EAFs are shown in Fig. 1A. In total, 135 aged cows (average age: $160 \pm$ 2.2 months) were used.

\section{Culture of OGCS and IVM}

OGCs were individually transferred to wells containing $200 \mu \mathrm{l}$ of medium (96-well plates, Becton, Dickinson and Company, Franklin Lakes, NJ, USA) and cultured for 16 days. Half of the medium was replaced with fresh medium, and antrum formation was examined at intervals of 4 days. After the culture period, OGCs having antra (Fig. 1B) were subjected to IVM for $23 \mathrm{~h}$, and almost all oocytes in OGCs without antra degenerated (Fig. 1C). For IVF, frozen-thawed semen from a Japanese Black Cow was used, and presumptive zygotes were cultured in IVC medium for 7 days as described previously [29]. At that time, embryos reached the blastocyst stage, and the total number of blastocysts was determined.

Measurement of mitochondrial DNA copy numbers in oocytes

Oocytes collected from EAFs of each donor and oocytes grown in vitro were individually lysed in $6 \mu$ lysis buffer (20 mM Tris, $0.4 \mathrm{mg} /$ $\mathrm{ml}$ proteinase $\mathrm{K}, 0.9 \%$ Nonidet $\mathrm{P} 40$, and $0.9 \%$ Tween 20 ) at $55 \mathrm{C}$ for
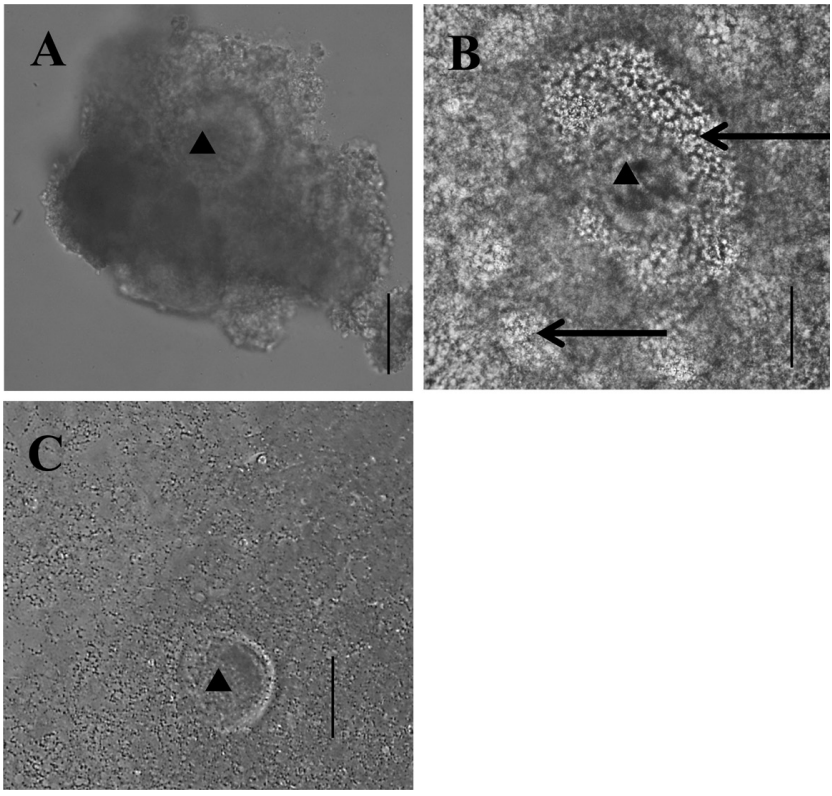

Fig. 1. Representative images of OGCs. A, OGCs collected from EAFs. B, OGCs cultured for 16 days and having formed an antrum. C, OGCs cultured for 16 days and not having formed an antrum. Oocytes seem degenerated. $\boldsymbol{\Delta}$ : Oocytes. $\rightarrow$ : Antrum. Scale bar represents $100 \mu \mathrm{m}$.

$30 \mathrm{~min}$ followed by incubation at $95 \mathrm{C}$ for $5 \mathrm{~min}$. Mt numbers were then determined by real-time PCR as described previously $[9,30]$.

\section{Detection of SIRT1 and LC3 by fluorescence immunostaining}

Oocytes were collected from OGCs cultured for 4 days in medium with 0 (vehicle) or $20 \mu \mathrm{M}$ resveratrol. The time point of 4 days was selected because antrum formation occurs between days 4 and 8 and almost all oocytes in OGCs without antrum formation degenerated (Fig. 1C); thus day 4 is the optimal time point to obtain enough viable oocytes for immunostaining. Immunostaining was conducted as described previously [17]. The primary antibodies were rabbit polyclonal anti-LC3 (1:500; Novus International, St. Charles, MO, USA) and rabbit polyclonal anti-SIRT1 (1:500; Santa Cruz Biotechnology, Santa Cruz, CA, USA), and fluorescein-conjugated goat anti-rabbit IgG (1:1000; Cell Signaling Technology, Beverly, MA, USA) was used as a secondary antibody. Oocytes were mounted on glass slides using an antifade reagent containing DAPI (ProLong Gold antifade reagent with DAPI; Invitrogen, Life Technologies, Carlsbad, CA, USA). The expression of SIRT1 was observed using a digital fluorescence microscope (BZ-8000; Keyence, Tokyo, Japan). Fluorescence images of the oocytes were captured, and the fluorescence intensity was measured using the NIH ImageJ software. The number of LC3 dots was observed using a fluorescence microscope (LAS AF; Leica Microsystems, Wetzlar, Germany). The numbers of LC3 dots in an equatorial region of the oocytes were counted under a fluorescent microscope (Leica LAS AF, Wetzlar, Germany).

\section{Western blot analysis}

OGCs were cultured in medium with 0 (vehicle) or $20 \mu \mathrm{M}$ 
resveratrol for 4 days. Oocytes and granulosa cells were then separated and lysed in $20 \mu$ of Laemmli sample buffer (Bio-Rad Laboratories, Hercules, CA, USA), and the proteins were extracted for $10 \mathrm{~min}$ at $95 \mathrm{C}$. Proteins were then separated by electrophoresis on $10 \%$ sodium dodecyl sulfate (SDS) polyacrylamide gels and were transblotted on polyvinylidene difluoride membranes (Bio-Rad transfer pack). Anti-LC3 (1:500; Novus International) or anti-SIRT1 (rabbit anti-SIRT1 IgG; Santa Cruz Biotechnology) and anti-actin (mouse anti-b-actin; Sigma) antibodies were used as primary antibodies. Anti-rabbit and anti-mouse horseradish peroxidase (HRP)-conjugated IgG (GE Healthcare, Buckinghamshire, UK) were used as secondary antibodies. Signal detection and densitometry analysis were performed using imageQuant LAS 4000 (GE Healthcare). The signal intensity of SIRT1 was normalized by that of actin, and the ratio of LC3-II to total LC3 (LC3-II / [LC3-I + LC3-II]) was calculated.

\section{ATP measurement}

OGCs cultured in vitro were subjected to IVM, after which the oocytes were removed from granulosa cells, and the ATP content in individual oocytes was measured. The ATP assay was conducted as previously described [19].

\section{Gene expression analysis}

Effects of resveratrol on the granulosa condition of OGCs were examined at the end of the culture period. OGCs from 34 donor cows $(160 \pm 3.5$ months of age) were cultured with 0 (vehicle) or $20 \mu \mathrm{M}$ resveratrol for 16 days, after which granulosa cells were collected $(\mathrm{n}=3$ replicates each). RNA extraction was performed using an RNAqueous kit (Life Technologies, Carlsbad, CA, USA). After an RNA quality check using a 2100 Bioanalyzer (Agilent Technologies, Palo Alto, CA, USA), libraries were prepared using a TruSeq RNA Sample Preparation Kit (Illumina, San Diego, CA, USA). Using these libraries, clusters were generated on an Illumina cBot, and two lanes for the six groups were sequenced as 50-bp reads (single end) on an Illumina HiSeq Sequencing System. Image analysis, base calling, and quality filtering were performed with CASAVA ver. 1.8.3. (Illumina) following the manufacturer's instructions. Derived sequence data were aligned to the bovine genome sequence (UMD3) to count the sequence reads. The read counts per transcript and RPKM values [31] were generated for all annotated genes. Genes that were significantly $(\mathrm{P}<0.05)$ differentially expressed were interpreted in the context of their biological processes or functions and by their networks and pathways by using IPA (Qiagen, Redwood City, CA, USA, www. qiagen.com/ingenuity). Fisher's exact test was used in the analysis of gene set enrichment in the functional categories.

\section{Experimental design}

Experiment 1: The effects of resveratrol on the expression of SIRT1 in oocytes and granulosa cells were examined by immunostaining and western blot analysis. OGCs were cultured with 0 (vehicle, ethanol) or $20 \mu \mathrm{M}$ resveratrol for 4 days. For immunostaining of oocytes, eight aged donor cows were used. For western blot analysis, granulosa cells collected from 35 OGCs were used, and sampling was repeated four times with different donors; in total, 19 aged cows were used.

Experiment 2: The effects of resveratrol on the number of autophagosomes in oocytes were examined. OGCs were cultured with
0 (vehicle) or $20 \mu \mathrm{M}$ resveratrol for 4 days, and the occurrence of autophagy was evaluated by examining the number of LC3 dots and the LC3-I/LC3-II band patterns in cells [32, 33]. The number of LC3 dots was determined by immunostaining, and the LC3 band pattern was determined by western blot analysis using granulosa cells collected from 35 OGCs. Sampling was repeated three times using a total of 18 different donors.

Experiment 3: The effects of resveratrol on Mt numbers were determined in oocytes grown in vitro. Twenty OGCs were collected from EAFs of each donor cow and divided into two groups. These OGCs were cultured in medium with 0 (vehicle) or $20 \mu \mathrm{M}$ resveratrol for 16 days. At the end of the culture period, oocytes were denuded from OGCs forming antra, and Mt numbers of oocytes were examined individually. In total, 13 cows were used.

Experiment 4: The effects of resveratrol on ATP content were determined in oocytes grown in vitro. Twenty OGCs were collected from EAFs of each donor cow and divided into two groups. These OGCs were cultured in medium with 0 (vehicle) or $20 \mu \mathrm{M}$ resveratrol for 16 days, after which OGCs having antra were cultured in IVM medium for $23 \mathrm{~h}$. ATP content in individual oocytes was then measured. In total, 17 cows were used.

Experiment 5: Here, we examined the effects of resveratrol on the in vitro development of oocytes derived from EAFs. Fifty-five OGCs were cultured in medium with 0 (vehicle) or $20 \mu \mathrm{M}$ resveratrol, and the rate of antrum formation was examined during 16 days of IVC. OGCs having antra were subjected to IVM, IVF, and IVC, and the rates of cleavage and blastulation were examined. The experiment was repeated 11 times using a total of 57 aged cows.

Experiment 6: In this experiment, the effects of resveratrol on the gene expression patterns of granulosa cells were examined. OGCs collected from EAFs of 34 aged cows were treated with 0 (vehicle) or $20 \mu \mathrm{M}$ resveratrol. At the end of the culture period (16 days), granulosa cells were collected from OGCs forming antra and were used for gene expression analysis.

\section{Statistical analysis and gene expression analysis}

Data were compared using Student's two-tailed $t$-tests. Development rates were arcsine transformed before analysis, and values less than 0.05 were considered significant. In gene expression analysis, statistical significance was determined by Fisher's exact test using edgeR [34]. Differences with $P$ values of less than 0.05 were considered significant.

\section{Results}

\section{Resveratrol increased SIRT1 levels in oocytes and granulosa} cells.

First, we examined the expression of SIRT1 in oocytes and granulosa cells following treatment with resveratrol. Figure 2 shows the expression of SIRT1 in oocytes and granulosa cells. Supplementation of culture medium with resveratrol increased SIRT1 expression by 1.7- and 2.0-fold in oocytes and granulosa cells, respectively $(\mathrm{P}<0.05)$.

\section{Resveratrol upregulated autophagy in oocytes and granulosa cells.}

Next, we examined the occurrence of autophagy in oocytes and granulosa cells treated with resveratrol by analyzing the expression 

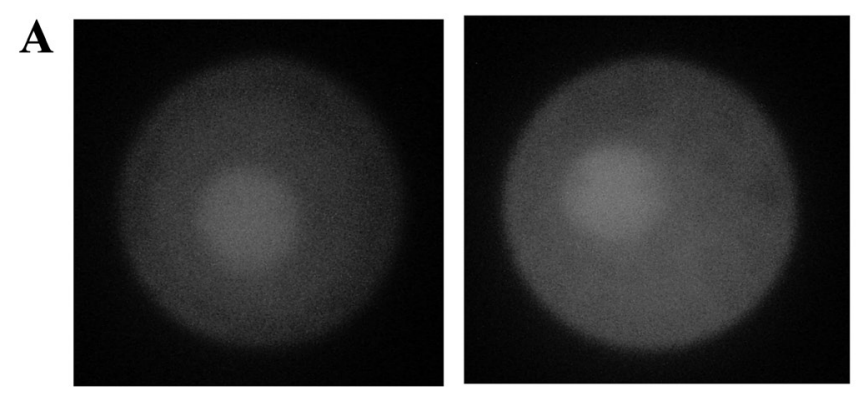

B

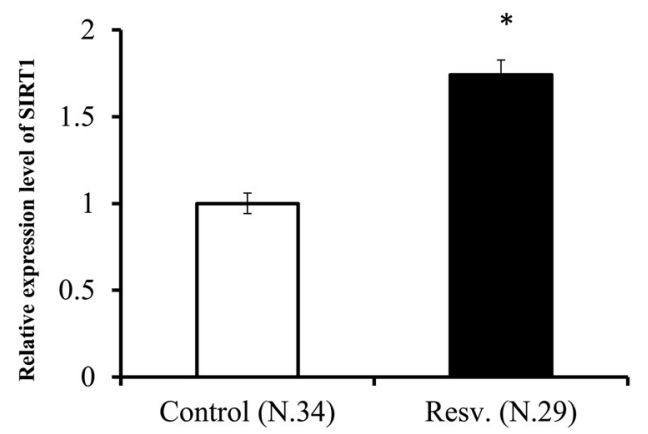

C

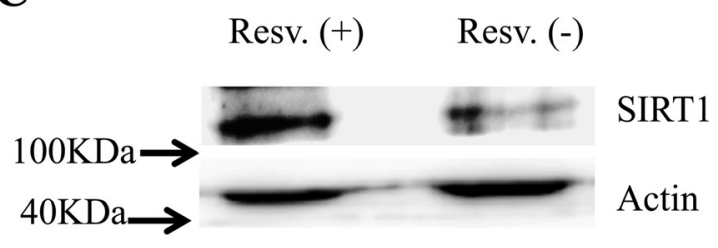

D

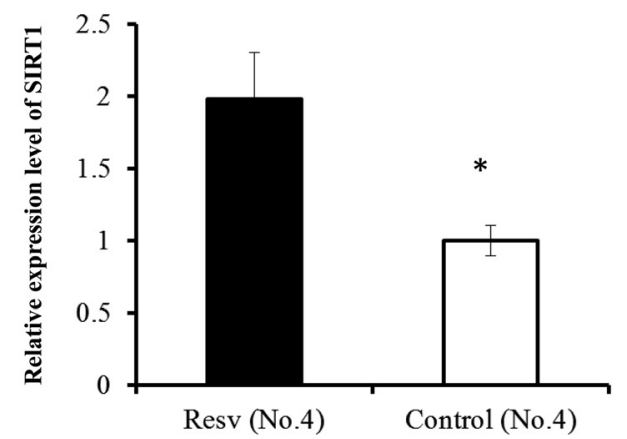

Fig. 2. Expression level of SIRT1 in oocytes (A vehicle, B resveratrol) and granulosa cells (C, D). A, SIRT1 was localized throughout the oocyte, but was more strongly present in the nucleus in both groups. B, Comparison of average SIRT1 expression levels, with the values are presented in proportion to the control (set as 1.0). C, SIRT1 and Actin expression measured by western blot analysis. D, Effects of resveratrol on the relative expression level of SIRT1 with respect to that of Actin. OGCs were cultured in medium containing $20 \mu \mathrm{M}$ resveratrol or vehicle (ethanol) for 4 days. Values were normalized to those of the control. * $\mathrm{P}<0.05$.

of the marker of autophagosomes. LC3 protein is generally found to be localized in autophagosome membranes and can be visualized as punctate structures using a fluorescence microscope. Alternatively, autophagosomes can be monitored by biochemical assay; such assay detects the conversion from LC3-I to LC3-II, which is clearly correlated with the number of autophagosomes, using antibodies against LC3 [33]. Supplementation of culture medium with resveratrol significantly increased the number of LC3 dots (Fig. 3). In addition, western blot analysis revealed that resveratrol increased the relative intensity of the LC3-II band with respect to total LC3 in both oocytes and granulosa cells (Fig. 4A-C).

Resveratrol increased $M t$ numbers in oocytes grown in vitro.

As shown in Fig. 5A, mitochondrial DNA copy numbers varied greatly among donor cows, and the average Mt numbers in oocytes increased from $440,424 \pm 48,319$ to $590,129 \pm 72,345$ following treatment with $20 \mu \mathrm{M}$ resveratrol (Fig. 5B). The difference between these two groups was not significant. However, when the mitochondrial DNA copy number in control oocytes of each donor was defined as 1.0 , the $\mathrm{Mt}$ number increased in almost all donors following resveratrol treatment (Fig. 5C), and the difference between untreated and resveratrol-treated oocytes was significant (Fig. 5D; 1.0 vs. $1.41 \pm 0.18, \mathrm{P}<0.05$ ).

Resveratrol increased ATP content in oocytes grown in vitro.

The ATP content in mature oocytes reflects developmental competence in cows and humans $[35,36]$. Therefore, we next examined the ATP content of oocytes following in vitro maturation. The average ATP content of in vitro mature oocytes varied substantially among
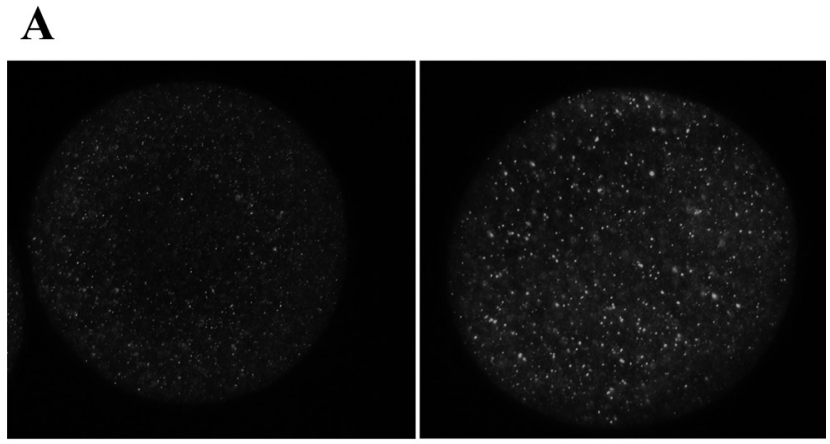

B

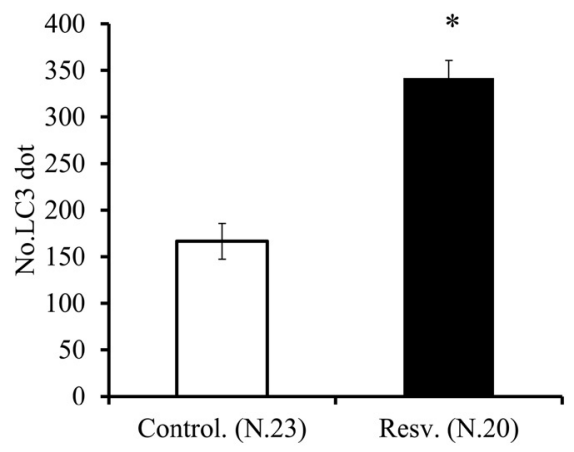

Fig. 3. Effects of resveratrol on the number of LC3 dots in oocytes observed by immunostaining. OGCs were cultured in medium containing $20 \mu \mathrm{M}$ resveratrol or vehicle (ethanol) for 4 days, and the oocytes were stained against LC3. A, LC3 in the autophagosome membrane was visualized as dots (left vehicle; right, resveratrol). B, Comparison of number of LC3 dots between the vehicle and resveratrol groups. ${ }^{*} \mathrm{P}<0.05$. 
A

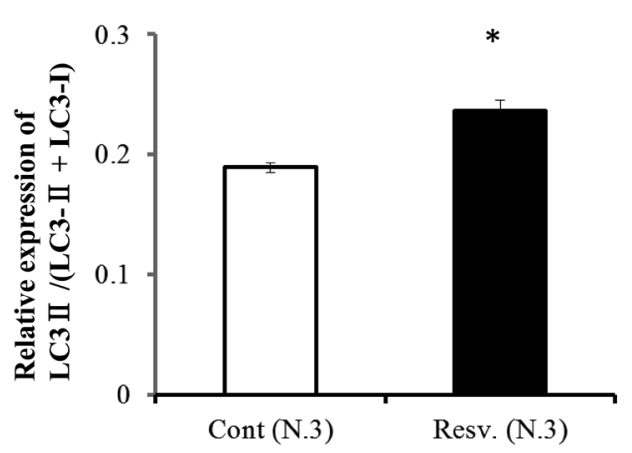

B

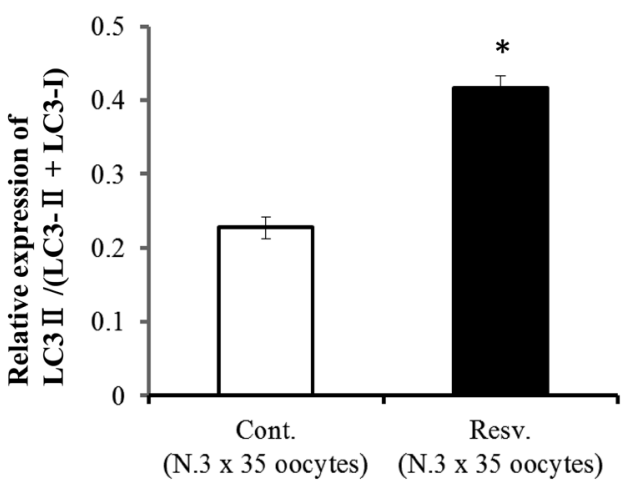

C

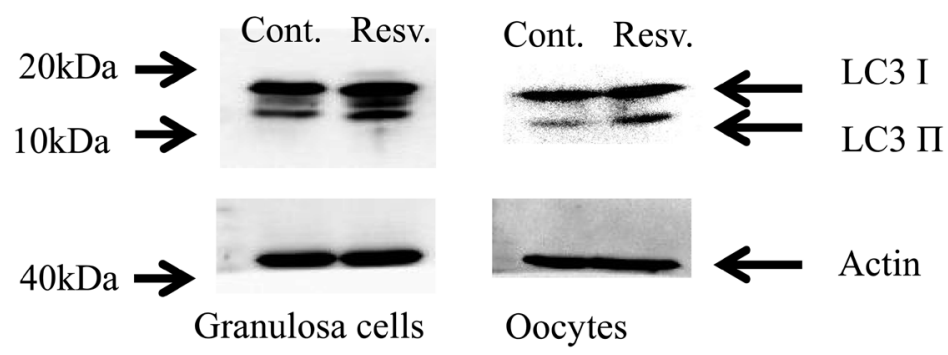

Fig. 4. Effects of resveratrol on LC3-II expression levels with respect to LC3 in oocytes (A) and granulosa cells (B). Conversion of LC3-I to LC3-II was detected by western blotting using antibodies against LC3. $* \mathrm{P}<0.05$.
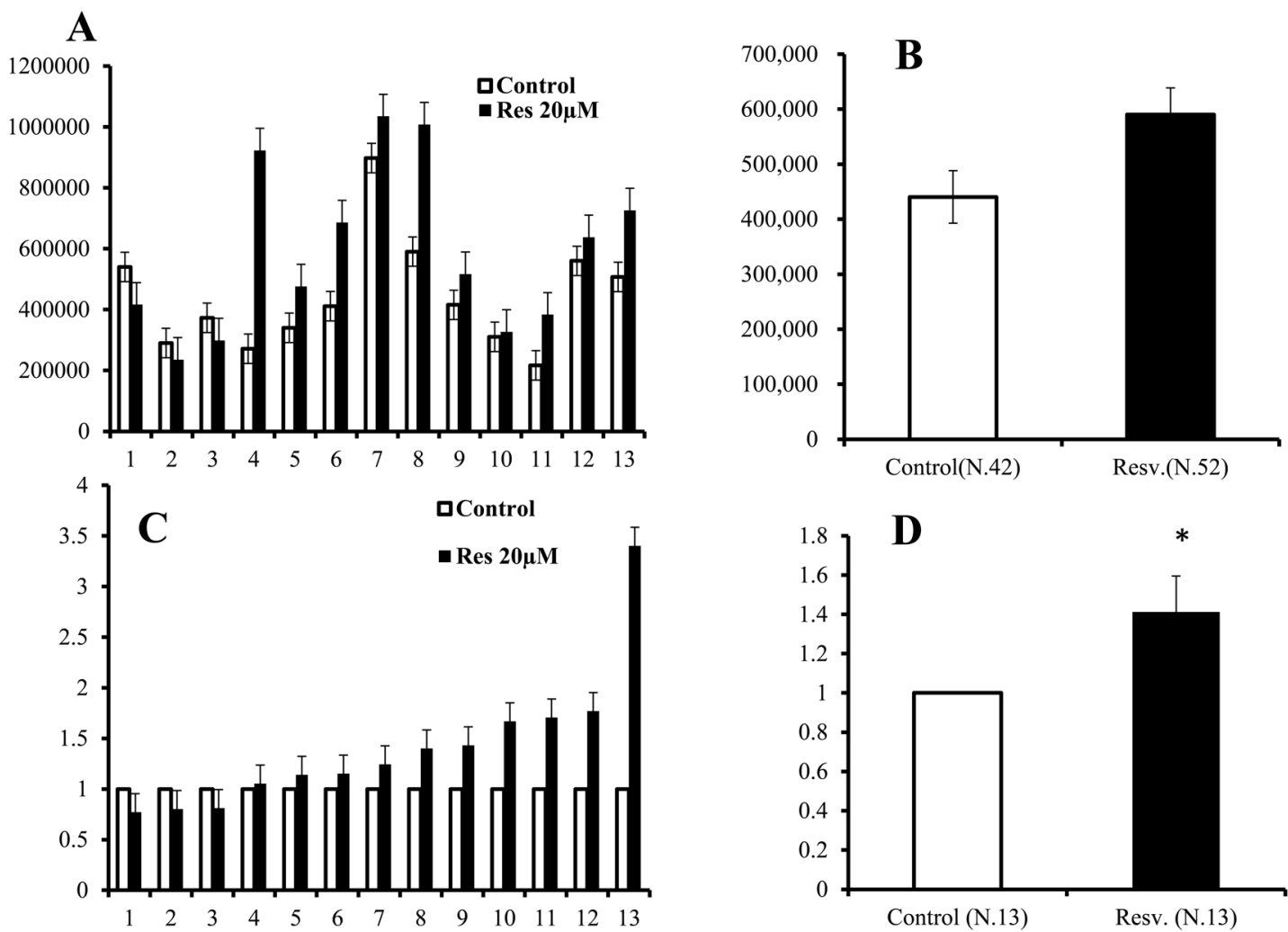

Fig. 5. Effects of a $20 \mu \mathrm{M}$ resveratrol concentration on the Mt number in oocytes grown in vitro (average \pm SEM). A, Average Mt number of oocyte for individual cows. White bar, control; black bar, resveratrol. X-axis: serial number, Y-axis: Mt number. B, Average Mt number of 13 donor cows. Y-axis: Mt number. C, Relative Mt number of individual cows. The Mt number of the control group was defined as 1.0. X-axis: serial number. Y-axis: relative Mt number. D, Average of the relative Mt number of 13 cows. Y-axis: relative Mt number. * $\mathrm{P}<0.05$. 
donors (Fig. 6A). Treatment with resveratrol induced a significant increase in ATP content compared with the control (1.95 vs. $3.1 \mathrm{pM}$, respectively, $\mathrm{P}<0.05$; Fig. $6 \mathrm{~B})$.

\section{Resveratrol improved the in vitro development of oocytes.}

Antrum-like cavities emerged beginning from day 4, and the rate of the antrum formation increased during the culture period. At the end of the culture period (16 days), the final antrum formation rate was $61.5 \pm 4.9 \%$ for the control group and $73.2 \pm 4.0 \%$ for the resveratrol group (Table 1); this difference was not significant $(\mathrm{P}=$ $0.10)$. Cleavage rates for oocytes grown with $20 \mu \mathrm{M}$ resveratrol in vitro after maturation and fertilization increased from $22.5 \pm 3.0 \%$ in the untreated control to $32.9 \pm 5.0 \%(\mathrm{P}=0.07)$. Furthermore, $6.3 \pm 2.2 \%$ of the OGCs treated with resveratrol developed to the blastocyst stage; this rate was significantly greater than that of the control group $(0.6 \pm 0.6 \%, \mathrm{P}=0.03$, Table 1$)$.

\section{Gene expression in the granulosa cell was profoundly affected by resveratrol.}

Next, we analyzed gene expression profiles using next-generation sequencing (NGS). We generated total of 122 and 142 million reads for granulosa cells cultured without or with $20 \mu \mathrm{M}$ resveratrol, respectively. The sequence data were deposited in the DDBJ Sequence Read Archive (DRA). The sequencing reads were aligned to the bovine genome sequence and uniquely mapped to known exons and splice junctions. Among the genes with mapped reads, Fisher's exact test revealed differentially expressed transcripts $(\mathrm{P}<0.05)$ between the two groups. We analyzed gene expression by using IPA to find top canonical pathway of genes with significant differential expression between untreated and resveratrol-treated oocytes. Long-term treatment of OGCs with resveratrol for 16 days altered the expression of genes involved in EIF2 signaling (Table 2) and upregulated genes related to protein synthesis (Supplementary Figs. 1 and 2: online only). In addition, mammalian target of rapamycin (mTOR) and tumor necrosis factor alpha $(\mathrm{TNF} \alpha)$ signaling were included in the top canonical pathways (Table 2). Genes associated with high developmental competence were expressed at higher levels in granulosa cells of OGCs cultured with resveratrol relative to those cultured without resveratrol (Table 3).

\section{Discussion}

The present study demonstrated that treatment of OGCs collected from the EAFs of aged cows with resveratrol increased de novo mitochondrial synthesis and autophagy during oocyte development. Moreover, resveratrol treatment increased ATP content in oocytes grown in vitro and improved the developmental ability of oocytes. In addition, we found that resveratrol had dramatic effects on gene expression in granulosa cells. Thus, our data provided important insights into the effects of resveratrol on oocyte development and mitochondrial quality.

The balance between mitochondrial biogenesis and degradation ultimately determines the quantity and quality of mitochondria in cells. In this study, we found that culturing OGCs with resveratrol for as little as 4 days enhanced the expression level of SIRT1 in oocytes and granulosa cells, thereby affecting mitochondrial biogenesis. Consistent
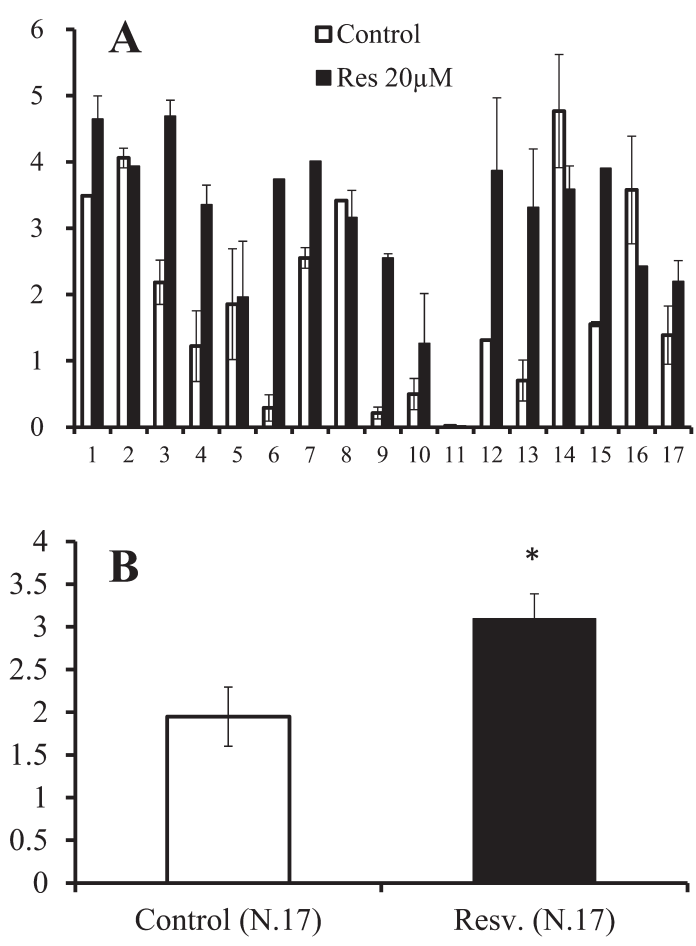

Fig. 6. Effects of $20 \mu \mathrm{M}$ resveratrol on the ATP contents (pM) in mature oocytes grown in vitro (average \pm SEM). Oocytes collected from individual donor cows were divided into two groups and grown with or without resveratrol for 16 days, after which the oocytes were further cultured for nuclear maturation. A, Average ATP content of matured oocytes for individual cows. X-axis: serial number. Y-axis: ATP content (pM). B, Average of 17 donor cows. Y-axis: ATP (pM). ${ }^{*} \mathrm{P}<0.05$.

with this, resveratrol is known to enhance mitochondrial biogenesis in somatic cells through upregulation of SIRT1 and AMPK [10, 37-39]. Moreover, resveratrol has been shown to be a potent activator of mitochondrial degeneration through autophagy $[15,40]$, a process that mediates cellular homeostasis by removing damaged mitochondria and other organelles [11]. Our data showed that autophagy was induced in response to resveratrol treatment in both oocytes and granulosa cells. These results suggested that mitophagy may occur in growing oocytes and that resveratrol may induce mitophagy in oocytes. In this context, Sato et al. [19] reported that resveratrol significantly enhanced both mitochondrial degeneration and de novo synthesis, resulting in mitochondrial replenishment and, therefore, improved oocyte competence. However, to the best of our knowledge, our study is the first report of autophagy in growing oocytes.

Mitochondrial DNA copy numbers increase during oocyte growth in vivo and in vitro $[2,30]$ and, the Mt number in mature oocytes is crucial for determining the developmental capacity of the oocytes [6]. On the other hand, decreased Mt numbers have been observed in in vitro matured oocytes and embryos collected from aged cows [9, 17]. Mt numbers differ greatly among cows, as has been reported for oocytes derived from both AFs and EAFs in cows [9, 30]. Consistent with these reports, we found that Mt numbers in oocytes grown in vitro varied dramatically among donor cows, thereby masking the 
Table 1. Effect of resveratrol on developmental ability of oocytes grown in vitro

\begin{tabular}{ccccccc}
\hline Resv $(\mu \mathrm{M})$ & No. of oocytes & No. of replicates & AF (\%) formation & Cleavage (\%) & Blastulation (\%) & No. of cells \\
\hline 0 & 158 & 11 & $61.5 \pm 4.9$ & $22.5 \pm 3.0$ & $0.6 \pm 0.6^{\mathrm{a}}$ & $79.5 \pm 6.7$ \\
20 & 158 & 11 & $73.2 \pm 4.0$ & $32.9 \pm 5.0$ & $6.3 \pm 2.2^{\mathrm{b}}$ & $67.7 \pm 5.6$ \\
\hline
\end{tabular}

$\mathrm{AF}$; antrum formation. Data are represented as mean \pm SEM. ${ }^{\mathrm{a}-\mathrm{b}} \mathrm{P}<0.05$.

Table 2. Top canonical pathway of genes with significantly differential expression between in the presence and absence of resveratrol

\begin{tabular}{ll}
\hline \multicolumn{1}{c}{ Name } & \multicolumn{1}{c}{ P-value Ratio } \\
\hline EIF2 Signaling & 4.89E-06 16/201 (0.08) \\
mTOR Signaling & $1.45 \mathrm{E}-03$ 12/213 (0.056) \\
TNFR1 Signaling & $4.14 \mathrm{E}-035 / 54(0.093)$ \\
Semaphorin Signaling in Neurons & $6.39 \mathrm{E}-035 / 54(0.093)$ \\
UDP-N-acetyl-D-glucosamine Bosynthesis II & $7.27 \mathrm{E}-032 / 17(0.118)$ \\
\hline
\end{tabular}

intrinsic changes induced by drugs. However, by comparing Mt numbers in untreated oocytes and resveratrol-treated oocytes collected from the same donor, we noted a significant 1.4-fold increase in $\mathrm{Mt}$ numbers in oocytes grown in vitro in the presence of resveratrol, indicating that resveratrol increased mitochondrial synthesis. The results suggested that resveratrol treatment of oocytes induced mitochondrial replenishment through upregulation of mitochondrial synthesis during oocytes growth.

Generation of ATP is one of the major functions of mitochondria, and the amount of ATP in mature oocytes reflects the quality of the oocytes $[37,41]$. In the present study, when oocytes in vitro grown were matured, resveratrol-treated oocytes exhibited a significantly increased ATP content compared with that in untreated oocytes, suggesting that resveratrol enhanced mitochondrial function. We further addressed the effects of resveratrol on oocyte developmental competence and found that resveratrol improved the rate of antrum formation of OGCs, the rate of cleavage of oocytes, and the rate of development to the blastocyst stage (note that the developmental rate was relatively low compared with the blastulation rate of oocytes derived from antral follicles [preliminary data showing 20-30\%]). In cows, the rate of development to the blastocyst stage of in vitro grown oocytes derived from EAFs is still very low compared with oocytes collected from antral follicles. Indeed, in previous studies using sophisticated culture conditions and semen in which over $40 \%$ of oocytes derived from AFs reached the blastocyst stage, the highest blastulation ratio per in vitro grown oocyte was only $11-15 \%$ in cows $[42,43]$. Thus, our data supported the notion that resveratrol improved the quality of oocytes derived from EAFs of aged cows.

Oocyte development depends on the interaction with surrounding granulosa cells [44]. We have shown that the gene expression profiles of granulosa cells in EAFs of aged cows differed from those of their younger counterparts, indicating that the low quality of granulosa cells of aged cows may be an attractive target for possible counteracting of the age-associated deterioration of oocytes [26]. In addition, the high developmental ability of oocytes is associated with the high expression levels of certain genes in granulosa cells [45-55]. In this context, we examined the effects of resveratrol on gene expression
Table 3. Marker gene of granulosa cells associated with developmental competence oocytes and embryos and genes discussed in the text

\begin{tabular}{|c|c|c|c|c|c|c|}
\hline \multirow{2}{*}{ Name } & \multicolumn{4}{|c|}{ RPKM } & \multirow{2}{*}{$\begin{array}{c}\text { Category } \\
\text { No. }\end{array}$} & \multirow{2}{*}{ Ref No. } \\
\hline & Control & Resv. & $\mathrm{R} / \mathrm{C}$ & P Value & & \\
\hline$A N K R D 1$ & 6.90 & 14.58 & 2.11 & 0.03 & 1 & [54] \\
\hline$A N X A 1$ & 13.83 & 21.06 & 1.52 & 0.01 & 1 & [54] \\
\hline$A T G 12$ & 16.87 & 22.11 & 1.31 & 0.02 & 2 & [48] \\
\hline$B M P R 1 B$ & 24.18 & 30.61 & 1.27 & 0.04 & 1 & [54] \\
\hline DDIT4 & 29.80 & 41.27 & 1.38 & 0.02 & 2 & [52] \\
\hline$F A S N$ & 86.39 & 63.58 & 0.74 & 0.00 & 2 & [49] \\
\hline GFPT2 & 2.70 & 4.30 & 1.59 & 0.03 & 1 & [54] \\
\hline$I G F 2$ & 3.65 & 10.09 & 2.77 & 0.01 & 1 & {$[46,54]$} \\
\hline$I G F B P 3$ & 15.81 & 22.53 & 1.43 & 0.03 & 1 & [46] \\
\hline INSIGI & 17.92 & 13.84 & 0.77 & 0.01 & 2 & [49] \\
\hline РTX3 & 16.63 & 23.93 & 1.44 & 0.00 & 1 & [45] \\
\hline SATI & 75.38 & 110.69 & 1.47 & 0.00 & 2 & [49] \\
\hline SREBF1 & 33.45 & 23.23 & 0.69 & 0.00 & 2 & {$[48,49]$} \\
\hline STAR & 1.30 & 3.03 & 2.33 & 0.02 & 1 & [47] \\
\hline TNFAIP6 & 1.62 & 4.16 & 2.57 & 0.01 & 1 & [55] \\
\hline TWISTI & 3.11 & 6.30 & 2.02 & 0.00 & 2 & [50] \\
\hline
\end{tabular}

Category 1; Genes whose expression level in granulosa cells associate to developmental competence of oocytes and embryos. 2, Genes of interest discussed in text.

profiles of granulosa cells. Similar to the results of the abovementioned studies, gene expression analyses in our study also showed that the expression levels of various genes were upregulated in granulosa cells cultured with resveratrol compared with untreated cells (Table 3). These results provide further evidence that resveratrol supports the acquisition of enhanced developmental ability in oocytes by improving the condition of granulosa cells. Moreover, IPA showed that resveratrol affected the expression of genes involved in EIF2, mTOR, and inflammation signaling pathways. As shown in Supplementary Figs. 1 and 2 (online only), resveratrol-treated granulosa cells exhibited higher expression of ribosome-related genes, indicating that these cells also had relatively high translation rates. Phosphorylation of EIF2A is the first step in the cellular stress response, and SIRT1 maintains low EIF2 phosphorylation levels through direct interaction with EIF2A [56]. Genes associated with inflammation are closely affiliated with the cellular stress response, while SIRT1 is known to repress inflammatory pathways [57-59]. Petterson et al. [50] reported that low expression of TWIST1 is associated with high secretion of TNF $\alpha$, and Uyar et al. [55] also reported that high TWIST expression is a marker of cumulus and granulosa cells and indicated oocyte and embryo quality. In our study, we found that treatment of granulosa cells with resveratrol resulted in high TWIST1 expression (Table 3). In addition, genes associated with the nuclear factor-kappaB (NF- $\kappa \mathrm{B})$ 
pathway are altered under resveratrol treatment (Supplementary Fig. 1).

SIRT1 inhibits mTOR activity [58,60-62]. In the present study, the mTOR pathway was identified as being regulated by resveratrol; the expression level of DDIT4, a known repressor of mTOR signaling [63], was observed at high levels in resveratrol-treated granulosa cells (Table 3). Furthermore, mTOR increases FASN through activation of SREBF and inhibits autophagy [58, 61]. Consistent with this, we found that expression levels of SREBF and FASN were significantly reduced in response to resveratrol, and the expression of ATG12 (Table 3 ), an important factor involved in autophagy [15], was significantly increased in granulosa cells treated with resveratrol. In line with this, Prigione et al. [48] reported that osteosarcoma cells having a mitochondrial DNA mutation exhibited high levels of SREBF1 and low levels of ATG12. These data support the notion that resveratrol treatment improves the condition of granulosa cells, resulting in the growth of high-quality oocytes in vitro. It is noteworthy that although these results are promising, there are some limitations in the study exists such as the effect of resveratrol on oocytes derived from EAFs of young cows. Our previous study [26] shows that the developmental stage and ability of oocytes, optimal culture condition for in vitro growth of oocytes and molecular background of the granulosa cells in EAFs differ to a great extent between young cows and aged cows. Furthermore, autophagic states in oocytes of EAFs differ between the two age groups (Supplementary Fig. 3: online only). Thus, the present study focuses on only aged cows and how resveratrol affect oocytes of young cows remains elusive.

In conclusion, supplementation of in vitro growth medium with resveratrol induced mitochondrial generation and autophagy in oocytes, which may replenish the quality of oocytes derived from EAFs of aged cows (Fig. 7). These data have important implications in the fields of reproduction and oocyte biology, and further studies are required to determine whether resveratrol may have therapeutic applications in the treatment of infertility or other reproduction-related disorders the clinical setting.

\section{Acknowledgement}

This study was supported by the Promotion and Mutual Aid Corporation for Private Schools of Japan and the Ministry of Education, Culture, Sports, Science, and Technology (Grant-in-Aid for Scientific Research [S0801025]) and by a Grant-in-Aid for Scientific Research C (KAKENHI, grant number: 25450400) from the Japan Society for the Promotion of Science.

\section{References}

1. Mahrous E, Yang Q, Clarke HJ. Regulation of mitochondrial DNA accumulation during oocyte growth and meiotic maturation in the mouse. Reproduction 2012; 144: 177-185. [Medline] [CrossRef]

2. Cotterill M, Harris SE, Collado Fernandez E, Lu J, Huntriss JD, Campbell BK, Picton HM. The activity and copy number of mitochondrial DNA in ovine oocytes throughout oogenesis in vivo and during oocyte maturation in vitro. Mol Hum Reprod 2013; 19: 444-450. [Medline] [CrossRef]

3. Reynier P, May-Panloup P, Chrétien MF, Morgan CJ, Jean M, Savagner F, Barrière P, Malthièry Y. Mitochondrial DNA content affects the fertilizability of human oocytes. Mol Hum Reprod 2001; 7: 425-429. [Medline] [CrossRef]

4. May-Panloup P, Chrétien MF, Jacques C, Vasseur C, Malthièry Y, Reynier P. Low oocyte mitochondrial DNA content in ovarian insufficiency. Hum Reprod 2005; 20 : 593-597. [Medline] [CrossRef]

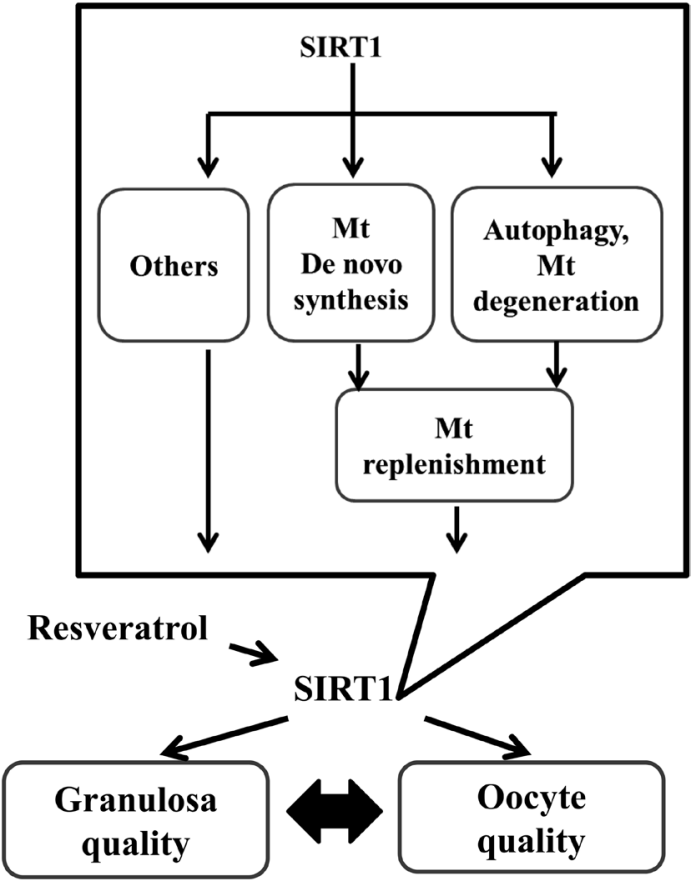

Fig. 7. Schematic model of the effect of SIRT1 on oocytes and granulosa cells cultured in vitro. Resveratrol upregulates the expression of SIRT1 in both oocytes and granulosa cells and improves oocytes development and granulosa cell quality. The beneficial effect of resveratrol on both types of follicular cells includes mitochondrial replenishment, likely through upregulation of mitochondrial generation and degeneration. Considering the versatile effects of resveratrol, including energy metabolism, mitochondrial respiration, adaptation to various cellular stresses (part of which are revealed by the present NGS analysis), and interactions between oocytes and granulosa cells, resveratrol affects the overall conditions of OGCs to improve the in vitro growth of oocytes derived from EAFs of aged cows.

5. Santos TA, El Shourbagy S, St John JC. Mitochondrial content reflects oocyte variability and fertilization outcome. Fertil Steril 2006; 85: 584-591. [Medline] [CrossRef]

6. May-Panloup P, Chretien MF, Malthiery Y, Reynier P. Mitochondrial DNA in the oocyte and the developing embryo. Curr Top Dev Biol 2007; 77: 51-83. [Medline] [CrossRef]

7. Hamatani T, Falco G, Carter MG, Akutsu H, Stagg CA, Sharov AA, Dudekula DB, VanBuren V, Ko MS. Age-associated alteration of gene expression patterns in mouse oocytes. Hum Mol Genet 2004; 13: 2263-2278. [Medline] [CrossRef]

8. Tatone C, Carbone MC, Falone S, Aimola P, Giardinelli A, Caserta D, Marci R, Pandolfi A, Ragnelli AM, Amicarelli F. Age-dependent changes in the expression of superoxide dismutases and catalase are associated with ultrastructural modifications in human granulosa cells. Mol Hum Reprod 2006; 12: 655-660. [Medline] [CrossRef]

9. Iwata H, Goto H, Tanaka H, Sakaguchi Y, Kimura K, Kuwayama T, Monji Y. Effect of maternal age on mitochondrial DNA copy number, ATP content and IVF outcome of bovine oocytes. Reprod Fertil Dev 2011; 23: 424-432. [Medline] [CrossRef]

10. Price NL, Gomes AP, Ling AJ, Duarte FV, Martin-Montalvo A, North BJ, Agarwal B, Ye L, Ramadori G, Teodoro JS, Hubbard BP, Varela AT, Davis JG, Varamini B, Hafner A, Moaddel R, Rolo AP, Coppari R, Palmeira CM, de Cabo R, Baur JA, Sinclair DA. SIRT1 is required for AMPK activation and the beneficial effects of resveratrol on mitochondrial function. Cell Metab 2012; 15: 675-690. [Medline] [CrossRef]

11. Youle RJ, van der Bliek AM. Mitochondrial fission, fusion, and stress. Science 2012; 337: 1062-1065. [Medline] [CrossRef]

12. Ashrafi G, Schwarz TL. The pathways of mitophagy for quality control and clearance of mitochondria. Cell Death Differ 2013; 20: 31-42. [Medline] [CrossRef]

13. Cantó C, Auwerx J. Targeting sirtuin 1 to improve metabolism: all you need is $\mathrm{NAD}(+)$ ? Pharmacol Rev 2012; 64: 166-187. [Medline] [CrossRef]

14. Lee IH, Cao L, Mostoslavsky R, Lombard DB, Liu J, Bruns NE, Tsokos M, Alt FW, 
Finkel T. A role for the NAD-dependent deacetylase Sirt1 in the regulation of autophagy. Proc Natl Acad Sci USA 2008; 105: 3374-3379. [Medline] [CrossRef]

15. Kang HT, Hwang ES. Nicotinamide enhances mitochondria quality through autophagy activation in human cells. Aging Cell 2009; 8: 426-438. [Medline] [CrossRef]

16. Kulkarni SS, Cantó C. The molecular targets of resveratrol. Biochim Biophys Acta 2015; 1852: 1114-1123. [Medline]

17. Takeo S, Kawahara-Miki R, Goto H, Cao F, Kimura K, Monji Y, Kuwayama T, Iwata H. Age-associated changes in gene expression and developmental competence of bovine oocytes, and a possible countermeasure against age-associated events. Mol Reprod Dev 2013; 80: 508-521. [Medline] [CrossRef]

18. Takeo S, Sato D, Kimura K, Monji Y, Kuwayama T, Kawahara-Miki R, Iwata H. Resveratrol improves the mitochondrial function and fertilization outcome of bovine oocytes. $J$ Reprod Dev 2014; 60: 92-99. [Medline] [CrossRef]

19. Sato D, Itami N, Tasaki H, Takeo S, Kuwayama T, Iwata H. Relationship between mitochondrial DNA copy number and SIRT1 expression in porcine oocytes. PLOS ONE 2014; 9: e94488. [Medline] [CrossRef]

20. Adams GP. Comparative patterns of follicle development and selection in ruminants. $J$ Reprod Fertil Suppl 1999; 54: 17-32. [Medline]

21. Ireland JJ, Mihm M, Austin E, Diskin MG, Roche JF. Historical perspective of turnover of dominant follicles during the bovine estrous cycle: key concepts, studies, advancements, and terms. J Dairy Sci 2000; 83: 1648-1658. [Medline] [CrossRef]

22. Baerwald AR, Adams GP, Pierson RA. A new model for ovarian follicular development during the human menstrual cycle. Fertil Steril 2003; 80: 116-122. [Medline] [CrossRef]

23. Baerwald AR, Adams GP, Pierson RA. Characterization of ovarian follicular wave dynamics in women. Biol Reprod 2003; 69: 1023-1031. [Medline] [CrossRef]

24. Malhi PS, Adams GP, Mapletoft RJ, Singh J. Oocyte developmental competence in a bovine model of reproductive aging. Reproduction 2007; 134: 233-239. [Medline] [CrossRef]

25. Adams GP, Jaiswal R, Singh J, Malhi P. Progress in understanding ovarian follicular dynamics in cattle. Theriogenology 2008; 69: 72-80. [Medline] [CrossRef]

26. Itami N, Kawahara-Miki R, Kawana H, Endo M, Kuwayama T, Iwata H. Age-associated changes in bovine oocytes and granulosa cell complexes collected from early antral follicles. J Assist Reprod Genet 2014; 31: 1079-1088. [Medline] [CrossRef]

27. Takahashi Y, First NL. In vitro development of bovine one-cell embryos: Influence of glucose, lactate, pyruvate, amino acids and vitamins. Theriogenology 1992; 37: 963-978. [Medline] [CrossRef]

28. Yamamoto T, Iwata H, Goto H, Shiratuki S, Tanaka H, Monji Y, Kuwayama T. Effect of maternal age on the developmental competence and progression of nuclear maturation in bovine oocytes. Mol Reprod Dev 2010; 77: 595-604. [Medline] [CrossRef]

29. Takeo S, Goto H, Kuwayama T, Monji Y, Iwata $\mathbf{H}$. Effect of maternal age on the ratio of cleavage and mitochondrial DNA copy number in early developmental stage bovine embryos. J Reprod Dev 2013; 59: 174-179. [Medline] [CrossRef]

30. Endo M, Kimura K, Kuwayama T, Monji Y, Iwata H. Effect of estradiol during culture of bovine oocyte-granulosa cell complexes on the mitochondrial DNA copies of oocytes and telomere length of granulosa cells. Zygote 2014; 22: 431-439. [Medline]

31. Mortazavi A, Williams BA, McCue K, Schaeffer L, Wold B. Mapping and quantifying mammalian transcriptomes by RNA-Seq. Nat Methods 2008; 5: 621-628. [Medline] [CrossRef]

32. Ding WX, Ni HM, Li M, Liao Y, Chen X, Stolz DB, Dorn GW 2nd, Yin XM. Nix is critical to two distinct phases of mitophagy, reactive oxygen species-mediated autophagy induction and Parkin-ubiquitin-p62-mediated mitochondrial priming. J Biol Chem 2010; 285: 27879-27890. [Medline] [CrossRef]

33. Mizushima N, Yoshimori T, Levine B. Methods in mammalian autophagy research. Cell 2010; 140: 313-326. [Medline] [CrossRef]

34. Robinson MD, Oshlack A. A scaling normalization method for differential expression analysis of RNA-seq data. Genome Biol 2010; 11: R25. [Medline] [CrossRef]

35. Van Blerkom J, Davis PW, Lee J. ATP content of human oocytes and developmental potential and outcome after in-vitro fertilization and embryo transfer. Hum Reprod 1995; 10: 415-424. [Medline]

36. Stojkovic M, Machado SA, Stojkovic P, Zakhartchenko V, Hutzler P, Gonçalves PB, Wolf E. Mitochondrial distribution and adenosine triphosphate content of bovine oocytes before and after in vitro maturation: correlation with morphological criteria and developmental capacity after in vitro fertilization and culture. Biol Reprod 2001; 64: 904-909. [Medline] [CrossRef]

37. Cantó C, Gerhart-Hines Z, Feige JN, Lagouge M, Noriega L, Milne JC, Elliott PJ, Puigserver P, Auwerx J. AMPK regulates energy expenditure by modulating NAD + metabolism and SIRT1 activity. Nature 2009; 458: 1056-1060. [Medline] [CrossRef]

38. Park SJ, Ahmad F, Philp A, Baar K, Williams T, Luo H, Ke H, Rehmann H, Taussig R, Brown AL, Kim MK, Beaven MA, Burgin AB, Manganiello V, Chung JH. Resveratrol ameliorates aging-related metabolic phenotypes by inhibiting cAMP phosphodiesterases. Cell 2012; 148: 421-433. [Medline] [CrossRef]

39. Li YG, Zhu W, Tao JP, Xin P, Liu MY, Li JB, Wei M. Resveratrol protects cardiomyocytes from oxidative stress through SIRT1 and mitochondrial biogenesis signaling pathways. Biochem Biophys Res Commun 2013; 438: 270-276. [Medline] [CrossRef]

40. Wu Y, Li X, Zhu JX, Xie W, Le W, Fan Z, Jankovic J, Pan T. Resveratrol-activated
AMPK/SIRT1/autophagy in cellular models of Parkinson's disease. Neurosignals 2011; 19 163-174. [Medline] [CrossRef]

41. Slotte H, Gustafson O, Nylund L, Pousette A. ATP and ADP in human pre-embryos. Hum Reprod 1990; 5: 319-322. [Medline]

42. Hirao Y, Itoh T, Shimizu M, Iga K, Aoyagi K, Kobayashi M, Kacchi M, Hoshi H, Takenouchi N. In vitro growth and development of bovine oocyte-granulosa cell complexes on the flat substratum: effects of high polyvinylpyrrolidone concentration in culture medium. Biol Reprod 2004; 70: 83-91. [Medline] [CrossRef]

43. Huang W, Nagano M, Kang SS, Yanagawa Y, Takahashi Y. Effects of in vitro growth culture duration and prematuration culture on maturational and developmental competences of bovine oocytes derived from early antral follicles. Theriogenology 2013; 80: 793-799. [Medline] [CrossRef]

44. Orisaka M, Tajima K, Tsang BK, Kotsuji F. Oocyte-granulosa-theca cell interactions during preantral follicular development. J Ovarian Res 2009; 2: 9. [Medline] [CrossRef]

45. Zhang X, Jafari N, Barnes RB, Confino E, Milad M, Kazer RR. Studies of gene expression in human cumulus cells indicate pentraxin 3 as a possible marker for oocyte quality. Fertil Steril 2005; 83(Suppl 1): 1169-1179. [Medline] [CrossRef]

46. Wang TH, Chang CL, Wu HM, Chiu YM, Chen CK, Wang HS. Insulin-like growth factor-II (IGF-II), IGF-binding protein-3 (IGFBP-3), and IGFBP-4 in follicular fluid are associated with oocyte maturation and embryo development. Fertil Steril 2006; 86: 1392-1401. [Medline] [CrossRef]

47. Feuerstein P, Cadoret V, Dalbies-Tran R, Guerif F, Bidault R, Royere D. Gene expression in human cumulus cells: one approach to oocyte competence. Hum Reprod 2007; 22. 3069-3077. [Medline] [CrossRef]

48. Prigione A, Cortopassi G. Mitochondrial DNA deletions induce the adenosine monophosphate-activated protein kinase energy stress pathway and result in decreased secretion of some proteins. Aging Cell 2007; 6: 619-630. [Medline] [CrossRef]

49. Saito K, Ohta Y, Sami M, Kanda T, Kato $\mathbf{H}$. Effect of mild restriction of food intake on gene expression profile in the liver of young rats: reference data for in vivo nutrigenomics study. Br J Nutr 2010; 104: 941-950. [Medline] [CrossRef]

50. Pettersson AT, Mejhert N, Jernås M, Carlsson LM, Dahlman I, Laurencikiene J, Arner P, Rydén M. Twist1 in human white adipose tissue and obesity. J Clin Endocrinol Metab 2011; 96: 133-141. [Medline] [CrossRef]

51. Wu LL, Russell DL, Norman RJ, Robker RL. Endoplasmic reticulum (ER) stress in cumulus-oocyte complexes impairs pentraxin-3 secretion, mitochondrial membrane potential (DeltaPsi m), and embryo development. Mol Endocrinol 2012; 26: 562-573. [Medline] [CrossRef]

52. Dennis MD, McGhee NK, Jefferson LS, Kimball SR. Regulated in DNA damage and development 1 (REDD1) promotes cell survival during serum deprivation by sustaining repression of signaling through the mechanistic target of rapamycin in complex 1 (mTORC1). Cell Signal 2013; 25: 2709-2716. [Medline] [CrossRef]

53. Endo M, Kawahara-Miki R, Cao F, Kimura K, Kuwayama T, Monji Y, Iwata H. Estradiol supports in vitro development of bovine early antral follicles. Reproduction 2013; 145 85-96. [Medline] [CrossRef]

54. Nivet AL, Vigneault C, Blondin P, Sirard MA. Changes in granulosa cells' gene expression associated with increased oocyte competence in bovine. Reproduction 2013; 145: 555-565. [Medline] [CrossRef]

55. Uyar A, Torrealday S, Seli E. Cumulus and granulosa cell markers of oocyte and embryo quality. Fertil Steril 2013; 99: 979-997. [Medline] [CrossRef]

56. Ghosh HS, Reizis B, Robbins PD. SIRT1 associates with eIF2-alpha and regulates the cellular stress response. Sci Rep 2011; 1: 150. [Medline] [CrossRef]

57. Yoshizaki T, Schenk S, Imamura T, Babendure JL, Sonoda N, Bae EJ, Oh DY, Lu M, Milne JC, Westphal C, Bandyopadhyay G, Olefsky JM. SIRT1 inhibits inflammatory pathways in macrophages and modulates insulin sensitivity. Am J Physiol Endocrinol Metab 2010; 298: E419-E428. [Medline] [CrossRef]

58. Salminen A, Kaarniranta K. AMP-activated protein kinase (AMPK) controls the aging process via an integrated signaling network. Ageing Res Rev 2012; 11: 230-241. [Medline] [CrossRef]

59. Yang H, Zhang W, Pan H, Feldser HG, Lainez E, Miller C, Leung S, Zhong Z, Zhao H, Sweitzer S, Considine T, Riera T, Suri V, White B, Ellis JL, Vlasuk GP, Loh C. SIRT1 activators suppress inflammatory responses through promotion of p65 deacetylation and inhibition of NF-kB activity. PLoS ONE 2012; 7: e46364. [Medline] [CrossRef]

60. Demidenko ZN, Blagosklonny MV. At concentrations that inhibit mTOR, resveratrol suppresses cellular senescence. Cell Cycle 2009; 8: 1901-1904. [Medline] [CrossRef]

61. Gurusamy N, Lekli I, Mukherjee S, Ray D, Ahsan MK, Gherghiceanu M, Popescu LM, Das DK. Cardioprotection by resveratrol: a novel mechanism via autophagy involving the mTORC2 pathway. Cardiovasc Res 2010; 86: 103-112. [Medline] [CrossRef]

62. Liu M, Liu F. Resveratrol inhibits mTOR signaling by targeting DEPTOR. Commun Integr Biol 2011; 4: 382-384. [Medline] [CrossRef]

63. Lan YC, Chang CL, Sung MT, Yin PH, Hsu CC, Wang KC, Lee HC, Tseng LM, Chi CW. Zoledronic acid-induced cytotoxicity through endoplasmic reticulum stress triggered REDD1mTOR pathway in breast cancer cells. Anticancer Res 2013; 33: 3807-3814. [Medline] 